\begin{tabular}{|l|l|l||}
\hline \multicolumn{2}{|c|}{ PublisherInfo } \\
\hline \hline PublisherName & $:$ & BioMed Central \\
\hline \hline PublisherLocation & $:$ & London \\
\hline \hline PublisherImprintName & $:$ & BioMed Central \\
\hline \hline
\end{tabular}

\title{
Replication coupled to recombination
}

\begin{tabular}{|l|l|l||}
\hline \multicolumn{2}{|c|}{ ArticleInfo } \\
\hline \hline ArticleID & $:$ & 3813 \\
\hline \hline ArticleDOI & $:$ & $10.1186 /$ gb-spotlight-20001030-01 \\
\hline \hline ArticleCitationID & $:$ & spotlight-20001030-01 \\
\hline \hline ArticleSequenceNumber & $:$ & 250 \\
\hline \hline ArticleCategory & $:$ & Research news \\
\hline \hline ArticleFirstPage & $:$ & 1 \\
\hline \hline ArticleLastPage & $:$ & 2 \\
\hline \hline & $:$ & RegistrationDate : 2000-10-30 \\
ArticleHistory & $:$ & OnlineDate $\quad$ 2000-10-30 \\
\hline \hline ArticleCopyright & $:$ & BioMed Central Ltd2000 \\
\hline \hline ArticleGrants & $:$ & \\
\hline \hline ArticleContext & $:$ & 130591111 \\
\hline \hline
\end{tabular}




\section{William Wells}

Email: wells@biotext.com

Blocking meiotic DNA replication in budding yeast prevents recombination initiation. This could indicate a direct coupling of the two processes, or the presence of a checkpoint system that detects incomplete replication and shuts down the formation of double-strand breaks (DSBs). In the 27 October Science, Borde et al. report that budding yeast cells defective for the replication checkpoint can progress through meiosis I in the absence of replication, but DSBs are still not formed (Science 2000, 290:809-812). Furthermore, delaying replication in specific parts of the genome (by deleting origins of replication or creating translocations into telomeric regions) delays DSB formation only in those regions. Thus DSB formation is controlled locally, whereas the subsequent recombination and repair

processes are timed and controlled on a cell-wide basis. The 1.5 to 2 hour delay between replication and DSB formation may reflect the time needed to assemble protein complexes or to establish interhomolog contacts.

\section{References}

1. Recombination and hydroxyurea inhibition of DNA synthesis in yeast meiosis.

2. Science, [http://www.sciencemag.org/]

This PDF file was created after publication. 